\title{
Coagulase-Negative Staphylococci Contained in Gut Microbiota as a Primary Source of Sepsis in Low- and Very Low Birth Weight Neonates
}

\author{
Edyta Golińska ${ }^{1}$, Magdalena Strus ${ }^{2}{ }^{2} * \mathbb{D}$, Anna Tomusiak-Plebanek ${ }^{1}$, Grażyna Więcek ${ }^{1}$, \\ Łucja Kozien ${ }^{1}$, Ryszard Lauterbach ${ }^{2}$, Dorota Pawlik ${ }^{2}$, Beata Rzepecka-Węglarz ${ }^{3}$, \\ Jolanta Kędzierska ${ }^{4}$, Małgorzata Dorycka ${ }^{5}$ and Piotr B. Heczko ${ }^{1}$ \\ 1 Jagiellonian University Medical College, 31-121 Cracow, Poland; edyta.golinska@uj.edu.pl (E.G.); \\ a.tomusiak@uj.edu.pl (A.T.-P.); grazyna.wiecek@uj.edu.pl (G.W.); lucja.kozien@uj.edu.pl (Ł.K.); \\ piotr.heczko@uj.edu.pl (P.B.H.) \\ 2 Department of Neonatology, Jagiellonian University, Medical College, 31-501 Cracow, Poland; \\ ryszard.lauterbach@uj.edu.pl (R.L.); dorota.pawlik@uj.edu.pl (D.P.) \\ 3 Department of Neonatal Intensive Care, “UJASTEK” Medical Centre, 31-752 Cracow, Poland; \\ b.rzepecka@wp.pl \\ 4 Department of Microbiology, University Hospital, 31-501 Cracow, Poland; jkedzierska@su.krakow.pl \\ 5 Microbiological Laboratory, Diagnostics Inc. Krakow Branch, 31-864 Cracow, Poland; \\ malgorzata.dorycka@diag.pl \\ * Correspondence: magdalena.strus@uj.edu.pl
}

Received: 5 June 2020; Accepted: 30 July 2020; Published: 4 August 2020

check for updates

\begin{abstract}
Background: There are only a few reports in the literature about translocation of coagulasenegative staphylococci (CoNS) as a primary cause of sepsis in neonates, although CoNS are among a short list of "translocating" bacteria when present in abundance. Methods: 468 blood samples, 119 stool samples, and 8 catheter tips, from 311 neonates, were tested for presence of microorganisms. CoNS strains isolated from the blood and stool or from blood and catheter tip of the same newborn at approximately the same time were paired and typed with PFGE (Pulse-Field Gel Electrophoresis) method. The strains were then tested for the presence of adherence genes and biofilm formation. Results: The strains with identical PFGE profiles in comparison to those with non-identical profiles differed in terms of the pattern of the virulence genes and showed a lack of the genes related to adherence, but more often presence of IS256, which is related to virulence. They also were phenotypically unable to adhere to intestinal $\mathrm{Caco} 2$ cells. Conclusions: A considerable proportion of CoNS strains isolated from bloodstream of VLBW/LWB neonates was identical to the strains isolated from faeces of the same neonates at the same time. These observations may offer indirect evidence indicating that at least some CoNS can translocate from the gastrointestinal tract of the premature neonates into the bloodstream and thus cause generalized infection.
\end{abstract}

Keywords: sepsis; CoNS; staphylococcus; newborn; neonates; translocation

\section{Introduction}

Sepsis in low-birth-weight (LBW) and very low-birth-weight (VLBW) neonates is still one of the most significant causes of neonatal morbidity and mortality. Owing to the immature immune system and exposure to many invasive diagnostic and therapeutic procedures, LBW/VLBW neonates are at the highest risk for bacterial sepsis, with a prevalence of 1 to 5 per 1000 live births in developed countries [1,2]. The spectrum of bacterial pathogens of neonatal sepsis varies with the geographical area and time. Currently, in developed countries, coagulase-negative staphylococci (CoNS), such as 
S. epidermidis or S. haemolyticus, are the major pathogens involved in late-onset sepsis [3-5]. Data from the Polish Neonatology Surveillance Network also confirm this tendency. In the years 2009-2011, among microorganisms isolated from 1695 infants with VLBW, Gram-positive cocci, and mostly CoNS, predominated over other microorganisms [6].

It is commonly accepted that CoNS are able to induce clinically significant bacteraemia because of their natural niche on human skin and their ability to adhere to biomaterials and to form biofilm. Biofilm formation is the key mechanism of CoNS pathogenesis, particularly in relation to catheter-related infections [7]. It is believed, although not substantially documented, that single cells of the large CoNS populations present on the skin surface adhere to catheter material, colonize it, migrate along the catheter down through the wound and adjacent tissues to blood vessel lumen, and then multiply in the bloodstream [8]. Consistent with some reports, another possible pathomechanism of sepsis in LBW and VLBW neonates is translocation of bacteria from gut lumen to bloodstream due to increased intestinal permeability typical for premature neonates [9-11]. Some studies have demonstrated that Gram-negative bacteria can be translocated through the gut wall and reach the bloodstream either directly by invading submucosal capillary vessels or indirectly via Peyer's patches and lymphatics and cause bacteraemia and then sepsis [12-14].

There are only a few reports in the literature about translocation of CoNS as the primary cause of sepsis in neonates [15], although staphylococci and especially CoNS, according to some authors, are part of the short list of "translocating" bacteria when present in abundance [16,17].

Therefore, the aim of this study was to find evidence supporting the hypothesis that the primary source of the CoNS causing sepsis in LBW and VLBW neonates treated in neonatal intensive care units (NICU) is not only their skin but also gut microbiota. For this purpose, we used a standardized molecular typing PFGE method to compare DNA profiles of CoNS strains isolated from paired blood and stool samples of LBW and VLBW neonates with clinical signs of sepsis. Moreover, for selected CoNS strains we performed the adherence assay and tested for the presence of genes coding for different virulence factors.

\section{Materials and Methods}

\subsection{Patients}

A total of 311 LBW and VLBW neonates hospitalized in the Department of Neonatology, University Hospital, Jagiellonian University Medical College in Cracow and in the Department of Neonatal Intensive Care, Ujastek Medical Center in Cracow, in the years 2016-2017 with microbiologically confirmed sepsis, were included in the study. Neonates were monitored in the cooperating centers and appropriately cared for according to standards of medical care for neonates provided by the Polish Society of Neonatology. Late-onset sepsis (LOS) was defined according to criteria published by Gastmeier [18]:

- Presence of at least two of the following: temperature $>38^{\circ} \mathrm{C}$ or $<36.5^{\circ} \mathrm{C}$ or temperature instability, tachycardia or bradycardia, apnea, prolonged capillary refill, metabolic acidosis, hypoglycaemia, other signs of bloodstream infections such as lethargy;

- Recognized pathogen cultured from one or more blood cultures or CoNS isolated from at least one blood culture or intravascular line and one of the following: C-reactive protein $>2.0 \mathrm{mg} / \mathrm{dL}$, immature/total neutrophil ratio (I/T ratio) $>0.2$, leukocytes $<5000 / \mu \mathrm{L}$, platelets $<10,000 / \mu \mathrm{L}$.

\subsection{Ethics Approval}

This study was approved by the Bioethics Committee of Jagiellonian University Medical College no. 122.6120.222.2015. 


\subsection{Consent Form}

Informed Consent to Participate in a Research Study

Chair of Microbiology, Jagiellonian University Medical College

Department of Neonatology, Jagiellonian University Medical College

Department of Neonatal Intensive Care, "UJASTEK" Medical Centre

Title of Research Project: „A study on the mechanisms of the development of staphylococcal sepsis associated with catheters in newborns with very low birth weight"

PROCEDURES:

Blood samples will be routinely taken immediate after making presumptive diagnosis of sepsis. Stool samples will be taken as soon as possible after blood samples. Catheter tips will be cut off when routinely removed.

VOLUNTARY PARTICIPATION:

Your decision whether or not to participate in this study is voluntary. If you choose to participate in this study, you can withdraw your consent and discontinue participation at any time without prejudice.

QUESTIONS:

If you have any questions about the study, please contact prof. dr hab. Piotr Heczko. You can also contact prof. dr hab. med. Ryszard Lauterbach or dr n. med. Beata Rzepecka -Węglarz with any questions about the rights of research participants or research related concerns.

CONSENT:

YOU ARE MAKING A DECISION WHETHER OR NOT TO PARTICIPATE IN A RESEARCH STUDY. YOUR SIGNATURE BELOW INDICATES THAT YOU HAVE DECIDED TO PARTICIPATE IN THE STUDY AFTER READING ALL OF THE INFORMATION ABOVE ANDYOU UNDERSTAND THE INFORMATION IN THIS FORM, HAVE HAD ANY QUESTIONS ANSWERED AND HAVE RECEIVED A COPY OF THIS FORM FOR YOU TO KEEP.

Participant Signature Date

Research Signature Date

\section{Microbiological Cultures}

\subsection{Blood Samples}

Blood samples were routinely taken immediately after making presumptive diagnosis of sepsis and transported to the university hospital microbiological laboratory (UHML) or microbiological laboratory of the Diagnostyka Ltd., Cracow, Poland. Aseptically collected blood specimens of at least 1 millilitre volume were injected into an aerobic blood culture bottle (Bactec Plus 26 Aerobic; BD Microbiology Systems), incubated, and then subcultured on MacConkey agar, horse blood agar (at $37^{\circ} \mathrm{C}$, each for $24 \mathrm{~h}$ ), and Sabouraud agar (at $37^{\circ} \mathrm{C}$ for $38 \mathrm{~h}$ ). The isolates were identified using mass spectrometry (MALDI Biotyper, Bruker Scientific LLC, Billerica, MA, USA) according to manufacturer's instructions. Actual MBT IVD Library of mass spectra was applied. All isolates identified into species belonging to CoNS were transported to the Chair of Microbiology, Jagiellonian University Medical College (CM) for further investigations. They were checked for purity and kept frozen for further studies.

\subsection{Stool Samples}

Stool samples were collected from neonates with suspected sepsis as soon as possible after collecting blood samples. They were placed in transport media provided by the CM and kept frozen at $-70{ }^{\circ} \mathrm{C}$ until transported to $\mathrm{CM}$. The frozen samples were then homogenized in $1 \mathrm{~mL}$ of Schaedler's 
broth (SAB). The samples were plated on the following media: McConkey Agar (Oxoid, Hampshire, UK) for Enterobacteriaceae, Columbia Blood Agar (Difco, CA, USA) with 5\% sheep blood for staphylococci and streptococci and Enterococcosel Agar (BBL, MD, USA) for enterococci. The plates were incubated at $37^{\circ} \mathrm{C}$ aerobically for $24 \mathrm{~h}$. The morphology of the grown colonies was analyzed under magnifying glass, and several colony picks of each morphological type were subcultured on appropriate aerobic and anaerobic media and Gram-stained. Phenotypic identification was performed using commercial identification systems (API 20E, API20A, APIStaph, APIStrept (bioMerieux, l'Etoile, France).

All CoNS isolates were then speciated by mass spectrometry (as above) and kept frozen for further studies.

\subsection{Catheter Tips}

Catheter tips routinely removed from vessels close to the time of suspected sepsis were cut off by sterile scissors, placed in sterile tubes, and kept frozen at $-70{ }^{\circ} \mathrm{C}$ until transported to $\mathrm{CM}$. The catheters were checked for the presence of adherent bacteria using a semiquantitative roll-plate technique described previously by Maki, by transferring each catheter tip onto a plate with Columbia agar supplemented with $5 \%$ sheep blood and rolling the tip back and forth across the surface at least 3 to 4 times [19]. Colonies grown on roll-plates were identified as described above. All isolates initially identified as CoNS were speciated by mass spectrometry (as above), collected, and kept frozen for further studies.

\section{Molecular Typing}

Pulse-Field Gel Electrophoresis (PFGE) was used as the standard molecular typing technique for CoNS [20]. A protocol developed for CoNS and used in our laboratory on previous occasions was employed [21]. Differences in banding patterns were documented by Gel Compar (AppliedMaths, Sint-Martens-Latem, Belgium) using the Dice coefficient and unweighted pair group method with arithmetic mean. Isolates with more than $95 \%$ similarity were clustered together as identical.

\section{PCR Amplification of Genes Coding for Virulence Factors}

PCR (Polymerase Chain Reaction) technique was used to show presence or absence of the 5 genes coding virulence factors (icaA, sesI, sesD/bph, Hld, and IS256) attributed to biofilm formation, adherence to human epithelium and mucus, and host cell damage. The PCR reactions were performed in a BioRad (Hercules, CA, USA) thermocycler. Amplification was performed according to methodologies previously described [22-26]. Primers and PCR conditions are listed in Table 1.

Table 1. Primer sequences and polymerase chain reaction (PCR) conditions for various genetic markers.

\begin{tabular}{|c|c|c|c|c|c|}
\hline Gene & Forward Primer $\left(5^{\prime} \rightarrow 3^{\prime}\right)$ & Reverse Primer $\left(5^{\prime} \rightarrow 3^{\prime}\right)$ & $\begin{array}{l}\text { Product } \\
\text { Size (bp) }\end{array}$ & $\begin{array}{c}\text { PCR } \\
\text { Conditions }\end{array}$ & References \\
\hline icaA & AAA CTT GGT GCG GTT ACA GG & TCT GGG CCT GAC CAT GTT G & 750 & $\begin{array}{c}1 \min 94^{\circ} \mathrm{C} \\
30 \mathrm{~s} 57^{\circ} \mathrm{C} \\
1 \mathrm{~min} 72^{\circ} \mathrm{C} \\
39 \text { cycles }\end{array}$ & [26] \\
\hline IS256 & TGAAAAGCGAAGAGATTCAAAGC & ATGTAGGTCCATAAGAACGGC & 1102 & $\begin{array}{c}1 \mathrm{~min} 94^{\circ} \mathrm{C} \\
1 \min 59^{\circ} \mathrm{C} \\
90 \mathrm{~s} 72^{\circ} \mathrm{C} \\
34 \text { cycles }\end{array}$ & [23] \\
\hline sesD & TGCCAATCATCAAACCACTG & GTCACTGAACCGATTAACCCACTT & 635 & $\begin{array}{c}1 \min 94^{\circ} \mathrm{C} \\
1 \min 50^{\circ} \mathrm{C} \\
1 \min 72^{\circ} \mathrm{C} \\
30 \text { cycles }\end{array}$ & [25] \\
\hline sesI & GCT GAT TAT GTA AAT GAC TCA AAT & AGC TTT TGT TGT TTG AGC TTC & 389 & $\begin{array}{c}1 \min 95^{\circ} \mathrm{C} \\
1 \min 49^{\circ} \mathrm{C} \\
1 \min 72^{\circ} \mathrm{C} \\
34 \text { cycles }\end{array}$ & [22] \\
\hline Hld & ATG GCA GCA GAT ATC ATT TC & CGT GAG CTT GGG AGA GAC & 444 & $\begin{array}{c}2 \min 94^{\circ} \mathrm{C} \\
1 \min 45^{\circ} \mathrm{C} \\
1 \min 72^{\circ} \mathrm{C} \\
29 \text { cycles }\end{array}$ & [24] \\
\hline
\end{tabular}




\section{Adherence of CoNS to CaCo2 Cells}

The ability of the CoNS strains to adhere to the human gut epithelium was checked in vitro. Human intestinal epithelial cell line $\mathrm{CaCo} 2$ from colon carcinoma (American Type Culture Collection, Middlesex, United Kingdom) was used. The cells were grown in Dulbecco modified Eagle medium (DMEM)/F-12 (GIBCO, Carlsbad, CA, USA) supplemented with 10\% heat-inactivated foetal bovine serum (FBS) (GIBCO). The cells grew to confluence on 0.4-m semipermeable tissue culture inserts (Transwell; Corning, NY, USA) in a humidified incubator at $37^{\circ} \mathrm{C}$ and $5 \% \mathrm{CO}_{2}$. Briefly, $48 \mathrm{~h}$ culture of Caco-2 cells at a density of $1 \times 10^{6}$ cells $/ \mathrm{mL}$ were cultivated for $24 \mathrm{~h}$ in a 12 -well flat bottom tissue culture plate (Iwaki, Japan) on Eagle's 1959 medium (MEM; Biomed, Lublin, Poland) with L-glutamine and $\mathrm{NaHCO}_{3}$ (IITD, Wrocław, Poland) containing 5\% fetal calf serum (Sigma-Aldrich Chemie, Germany) and antibiotics (penicillin $100 \mathrm{UI} / \mathrm{mL}$, streptomycin $100 \mathrm{UI} / \mathrm{mL}$, neomycin $200 \mu \mathrm{g} / \mathrm{mL}$ ) (Sigma Aldrich Chemie, Germany) and then washed twice with PBS. Overnight cultures of bacteria were diluted with MRS+MEM to a concentration of $\sim 10^{8} \mathrm{CFU} / \mathrm{mL}$. Cells in wells were inoculated with bacterial culture. After incubation at $37^{\circ} \mathrm{C}$ for $30 \mathrm{~min}$, wells were washed twice with PBS to release unbound bacteria. Then, the cells were fixed with 3.7\% formaldehyde for $1 \mathrm{~h}$, washed twice with PBS, and stained with crystal violet stain (Merck, Germany). The adherent bacterial cells were counted in 20 randomly selected microscopic fields. Adhesion degree was evaluated using a semiquantitative score system, from (0) to (3), as used by us before [27] and based on the following legend:

(a) strong adherence (3): $>80$ bacterial cells per field

(b) moderate adherence (2): 61-80 bacterial cells per field

(c) weak adherence (1): 41-60 bacterial cells per field

(d) no adherence (0): $<40$ bacterial cells per field

All experiments were run in duplicate.

\section{Phenotypic Characteristic of Slime Production Ability on Congo Red Agar (CRA)}

All the strains were cultured on CRA plates. Plates were prepared by adding $0.8 \mathrm{~g}$ of Congo red (Sigma, St. Louis, MO, USA) and $36 \mathrm{~g}$ of saccharose (Sigma, St. Louis, MO, USA) to $1 \mathrm{~L}$ of brain heart infusion agar (Oxoid, Basingstoke, Hampshire, UK). Tested strains were incubated for $24 \mathrm{~h}$ at $37^{\circ} \mathrm{C}$ on CRA plates. Slime-producing strains form black and very black colonies, whereas non-producing strains develop red and bordeaux colonies, according to scale proposed by Arciola [28].

\section{Statistical Analyses}

Statistical analyses were performed to demonstrate significant differences in the presence of selected genes, and in the degrees of adherence and biofilm formation among tested CoNS strains. The Fisher exact test was used.

\section{Results}

Altogether 468 blood samples, 119 stool samples and 8 catheter tips from 311 neonates, were tested for presence of microorganisms. CoNS were the most commonly isolated group of bacteria, followed by Gram-negative rods (Table 2). In total, $443 \mathrm{CoNS}$ were isolated. Of these, 368 originated from blood, 69 from stool, and 6 from catheter tips. Among CoNS strains, these belonging to S. epidermidis species predominated over S. haemolyticus, S. capitis, and S. hominis; only a few strains belonged to other species.

Other bacteria isolated from blood samples were represented by 111 Gram-negative rods cultivated from all samples: 79 from blood and 32 from stool samples. They belonged to E. coli $(22.5 \%)$, K. pneumoniae (22.5\%), and K. oxytoca (20\%) species. Except for Gram-negative rods, various Streptococcus spp. and Candida spp. strains were found. 
Table 2. Microbial species isolated from blood, stool, and catheter tips from neonates with sepsis.

\begin{tabular}{|c|c|c|c|}
\hline Etiological Factors: & $\begin{array}{l}\text { Number of Isolates }(n=511) \\
\text { from } 468 \text { Blood Samples }\end{array}$ & $\begin{array}{l}\text { Number of Isolates }(n=148) \\
\text { from } 119 \text { Stool Samples }\end{array}$ & $\begin{array}{l}\text { Number of Isolates }(n=7) \\
\text { from } 8 \text { Catheter Tips }\end{array}$ \\
\hline Coagulase-negative staphylococci & $368(72 \%)$ & $82(55.4 \%)$ & $6(85.7 \%)$ \\
\hline S. epidermidis & 164 & 47 & 4 \\
\hline S. haemolyticus & 80 & 16 & 1 \\
\hline S. capitis & 58 & 2 & 0 \\
\hline S. hominis & 30 & 0 & 0 \\
\hline S. lugdunensis & 2 & 0 & 0 \\
\hline S. warneri & 2 & 1 & 0 \\
\hline S. xylosus & 1 & 0 & 0 \\
\hline S. caprae & 1 & 0 & 0 \\
\hline CNS & 30 & 16 & 1 \\
\hline Coagulase-positive staphylococci & $15(2.9 \%)$ & $4(2.7 \%)$ & $1(14.3 \%)$ \\
\hline S. aureus & 15 & 4 & 1 \\
\hline Gram negative rods & $79(15.5 \%)$ & $32(21.6 \%)$ & 0 \\
\hline Klebsiella spp. & 41 & 4 & 0 \\
\hline E. coli & 16 & 9 & 0 \\
\hline S. marcescens & 9 & 0 & 0 \\
\hline E. cloace & 7 & 0 & 0 \\
\hline P. mirabilis & 3 & 0 & 0 \\
\hline A. baumannii & 1 & 0 & 0 \\
\hline S. linguefaciens & 1 & 0 & 0 \\
\hline P. aeruginosa & 1 & 0 & 0 \\
\hline other & 0 & 19 & 0 \\
\hline $\begin{array}{l}\text { Other (Micrococcus spp., } \\
\text { Streptococcus spp., Candida spp.) }\end{array}$ & $49(9.6 \%)$ & $30(20.3 \%)$ & 0 \\
\hline
\end{tabular}

Further, CoNS strains isolated from the blood and stool or from blood and catheter tip of the same newborn at approximately the same time were paired and typed with PFGE method. Identity of the strains was confirmed using criteria of Tenover et al. [29]. Altogether, 69 pairs of CoNS strains isolated from blood and stool samples, and 6 CNS pairs isolated from blood and catheter tips, were compared (Table 3, Figure 1). It appeared that $26 \%$ of CoNS pairs from blood-stool group showed identical profile (pulsotype), which indicates that the same strain was isolated from blood as from stool. The rest of the pairs had different profiles, which means that different strains were isolated from blood and stool. No identical profiles were found for pairs from blood and catheter tips. The most common CoNS species occurring in pairs with the same pulsotype was S. haemolyticus $(67 \%)$, followed by S. epidermidis and S. capitis, while in pairs with non-identical profile it was S. epidermidis (55\% in blood-stool group, and $67 \%$ in blood-catheter tips group). Other pairs with non-identical profile belonged to $S$. warneri, S. hominis species, and CoNS strains not readily identified.

Occurrence of genes coding for adherence and biofilm formation in pairs of CoNS strains of the same or different PFGE profiles isolated from blood and stool samples was then analyzed (Figure 2). While identifying genes coding for selected virulence factors (ica A, ses D, sesI, Hld, IS256) in the genomes of CoNS strains, statistically significant differences in the frequencies of the icaA $(p<0.001)$ and IS256 $(p<0.01)$ in pairs of identical versus non-identical strains were confirmed. ica $A$ gene, responsible for the synthesis of adhesin forming the biofilm matrix, and sesI, encoding proteins responsible for colonization and adherence, were detected only in strains from blood-stool pairs with a non-identical PFGE profile. Moreover, sesD gene, also responsible for adherence, was found in 11/51 strains with non-identical profile, whereas it was present in $1 / 18$ strains in strains with identical profile. Hld gen was commonly found in most tested stains. On the other hand, sequence IS256 attributed to virulence was more frequently found in identical pairs of the strains than in non-identical ones. 
Table 3. Identity of the paired coagulase-negative staphylococci (CoNS) strains isolated from blood, catheter tips, and stool of the same patient at the same time, as compared with the Pulse-Field Gel Electrophoresis (PFGE) method.

\begin{tabular}{|c|c|c|c|c|c|c|}
\hline & \multicolumn{3}{|c|}{$\begin{array}{l}\text { Sample Pairs (Blood }+ \text { Stool) Taken } \\
\text { from the Same Newborn }(n=69)\end{array}$} & \multicolumn{3}{|c|}{$\begin{array}{l}\text { Sample Pairs (Blood + Catheter Tips) } \\
\text { Taken from the Same Newborn }(n=6)\end{array}$} \\
\hline & \multicolumn{4}{|c|}{ PFGE } & \multicolumn{2}{|c|}{ PFGE } \\
\hline & $\begin{array}{l}\text { Total } \\
\text { Number }\end{array}$ & $\begin{array}{l}\text { Identical } \\
\text { Profile }\end{array}$ & $\begin{array}{l}\text { Not Identical } \\
\text { Profile }\end{array}$ & $\begin{array}{l}\text { Total } \\
\text { Number }\end{array}$ & $\begin{array}{l}\text { Identical } \\
\text { Profile }\end{array}$ & $\begin{array}{l}\text { Not Identical } \\
\text { Profile }\end{array}$ \\
\hline Coagulaso negative staphylococci & 69 & 18 & 51 & 6 & 0 & 6 \\
\hline S. epidermidis & 32 & 4 & 28 & 4 & 0 & 4 \\
\hline S. haemolyticus & 22 & 12 & 10 & 1 & 0 & 1 \\
\hline S. capitis & 10 & 2 & 8 & 0 & 0 & 0 \\
\hline S. hominis & 2 & 0 & 2 & 0 & 0 & 0 \\
\hline S. warneri & 1 & 0 & 1 & 0 & 0 & 0 \\
\hline CNS & 2 & 0 & 2 & 1 & 0 & 1 \\
\hline
\end{tabular}

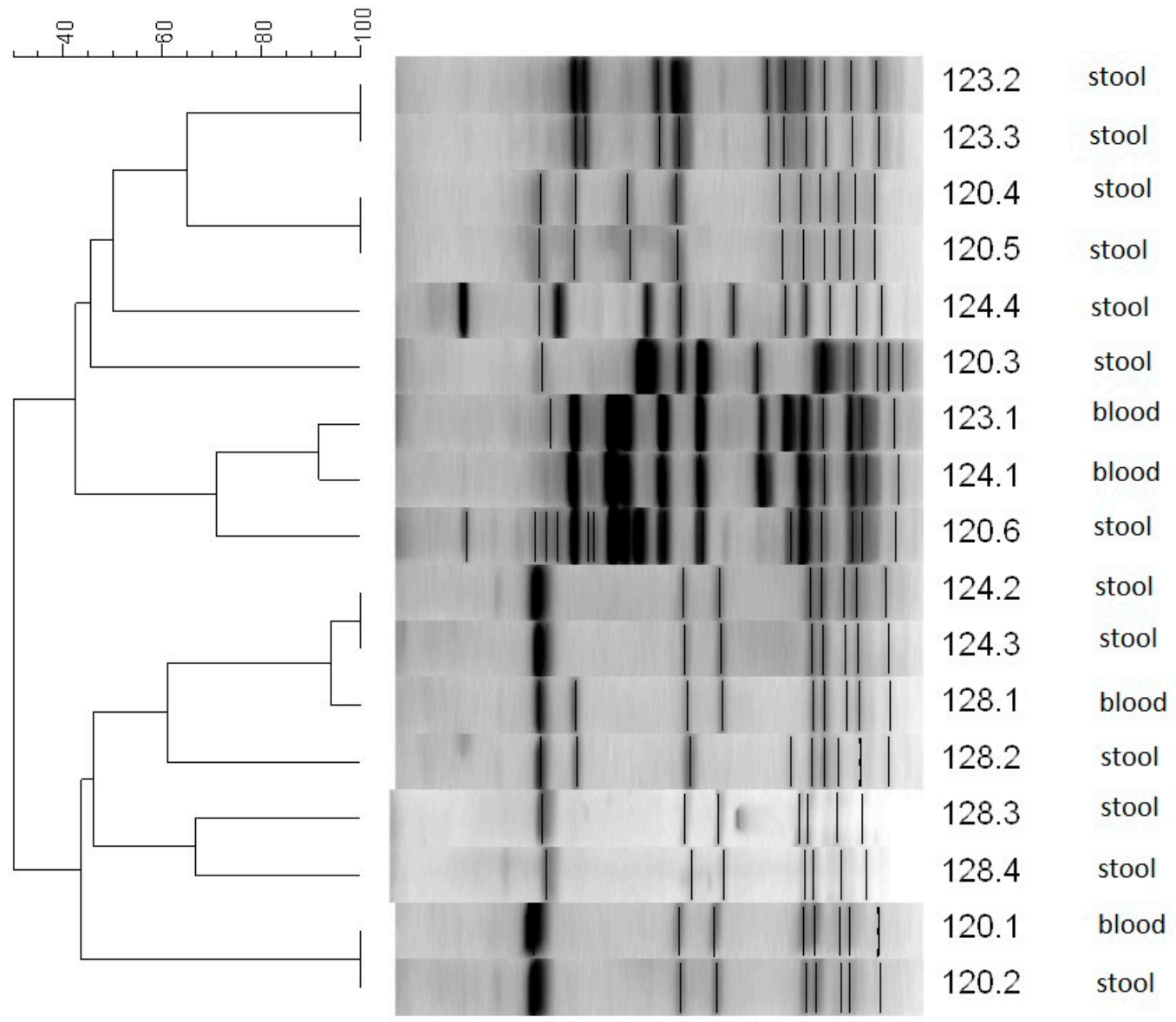

Figure 1. Dendrogram showing the percent similarity between CoNS isolated from blood and stool of four newborns $(120,123,124$, and 128) at the same time. Isolates were digested with SmaI restriction enzyme. PFGE band profiles are shown, and the scale indicates percent similarity. 


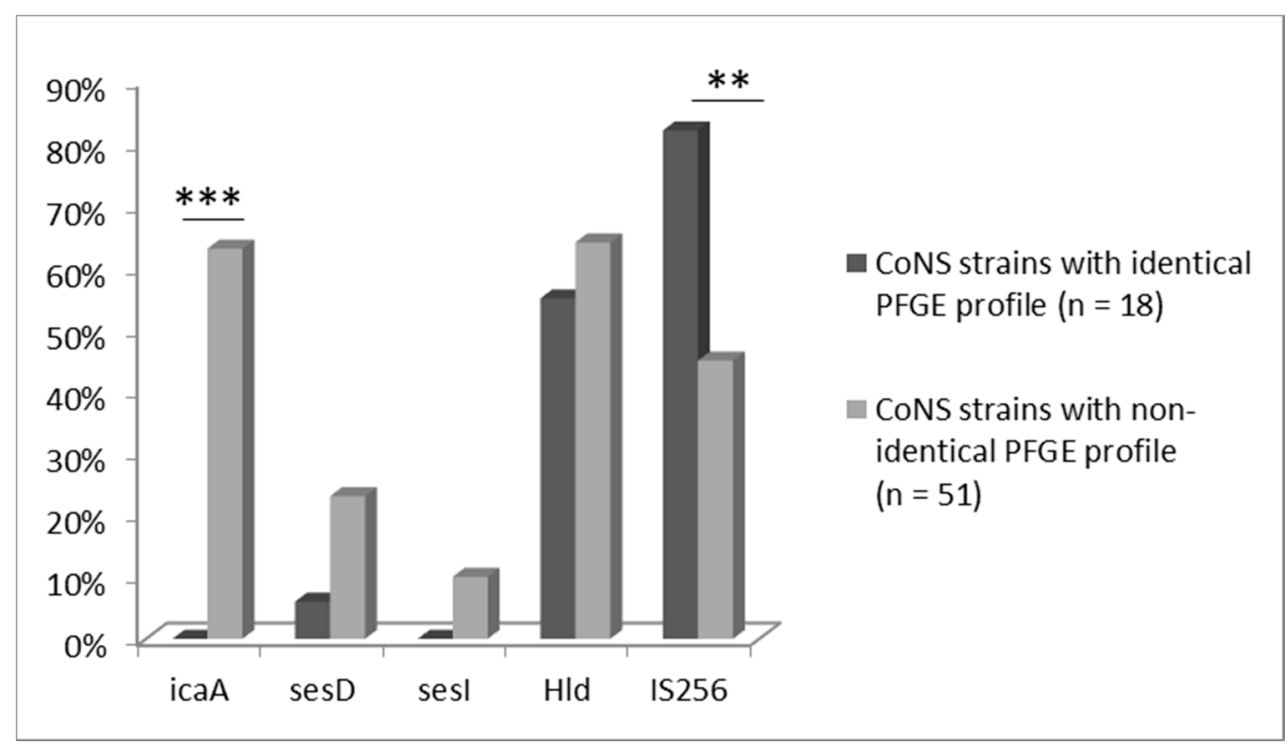

Figure 2. Proportional occurrence of tested virulence genes in CoNS strains $(n=69)$ isolated from blood, which have identical $(n=18)$ and non-identical $(n=51)$ PFGE profile with strains isolated from the stool samples $\left.(* * *) 0.001 ;{ }^{* *} p<0.01\right)$.

Adherence assay was performed on all 69 tested strains. It was observed that the strains from blood and stool with identical PFGE profiles showed a complete lack of adherence to $\mathrm{CaCo} 2$ tissue $(100 \%)$. On the contrary, strains with non-identical profiles presented ability to adhere in high proportions: $13.7 \%$ of strains showed strong, $17.6 \%$ intermediate, $25.5 \%$ weak adherence, and $43.1 \%$ lack of adherence. Statistically significant difference in adherence between both groups was confirmed $(p=0.0014)$ (Figure 3 ).

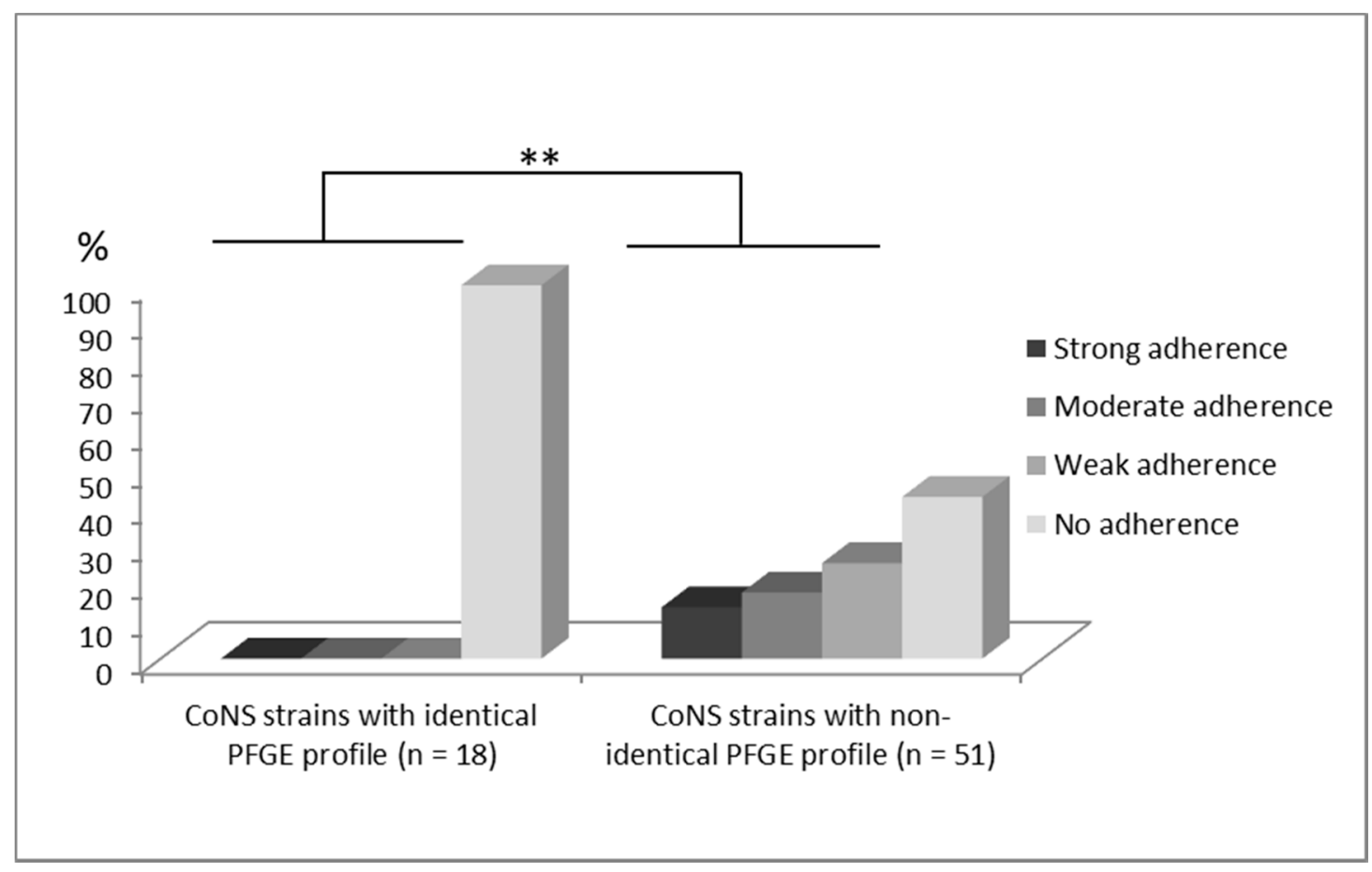

Figure 3. Comparison of degrees of adherence to Caco 2 cells evaluated in a semi-quantitative scale ( 0 -no adherence, 1 -weak adherence, 2 -moderate adherence, 3 -strong adherence) $\left({ }^{* *} p<0.01\right)$ between two tested CoNS groups isolated from blood, which have identical $(n=18)$ and non-identical $(n=51)$ PFGE profile with strains isolated from stool samples. 
The analyzed strains were examined for their ability to form biofilm. There were no biofilm-forming strains in CoNS group strains with identical PFGE profile. Only 9 of 51 strains from non-identical PFGE profiles group were able to produce biofilm. There were no statistically significant differences between tested groups.

\section{Discussion}

It is commonly accepted that bacteraemia and subsequent sepsis related to catheters inserted into blood vessels to deliver drugs in children treated in neonatal intensive care units (NICU) is caused by bacteria, mainly CoNS, which are members of the skin microbiota [30,31]. This hypothesis was partially confirmed in our study, where CoNS were the most commonly identified bacteria in the blood of premature newborns with low and very low birth weight and confirmed sepsis. However, the results of the PFGE typing, which enabled comparison of genetic profiles of the strains isolated from bloodstream and GI tract of the same neonates, showed that a small proportion of CoNS from these two sources had identical profiles. This may suggest that some of the CoNS translocate from the gastrointestinal tract into the bloodstream and thus cause generalized infection. The ability of CoNS to penetrate the intestinal barrier and translocate is not fully supported by literature data, but some researchers suggest that CoNS may have this attribute [17,32]. At the same time, no strain among those isolated from catheter tips showed identical profile with strains from the bloodstream. This may indicate that CoNS-colonizing catheters, which are probably derived from the skin microbiota, are not etiological CoNS strains related to sepsis.

It should be stressed here that in spite of the fact that complexity of the gut microbiota in premature neonates is not very high [33], isolation of CoNS strains from faeces to make pairs with their bloodstreamderived counterparts is difficult, and thus it may be so that a proportion of such strains has not been found in faecal cultures and in practice sepsis cases caused by gut-derived CoNS are more numerous.

Most common species of CoNS strains isolated from blood samples belonged to S. epidermidis and S. haemolyticus; however, the majority of the paired and identical strains were represented by S. haemolyticus, which may suggest that this species more often than other CoNS possess some mechanisms enabling them to translocate and cause a generalized infection. Our results are in accordance with studies of Soeorg et al. [17], in which 10 of 11 studied S. haemolyticus showed the genotypic similarity between bloodstream and gut isolates. The same group [34] reported later that S. haemolyticus, causing sepsis in neonates, originated mainly from intestines. They also demonstrated that mother's breast milk is the main source of neonatal gut colonization with CoNS.

Another evidence supporting the hypothesis that neonatal staphylococcal sepsis may be caused by CoNS strains colonizing gut of preterm infants comes from molecular studies on their genes related to their ability to adhere and form biofilm versus those attributed to virulence.

IcaA gene is responsible for the ability to create biofilm and adhere to host cells and artificial surfaces. The presence of this gene is an important factor in the virulence of CoNS. SesD gene, also called $b h p$, codes for a surface protein that facilitates bacterial adhesion to host tissue. Thus, these genes are responsible for facilitation of the colonization and spread in the hospital environment [25]. SesI gene is responsible for the intensity of virulence, but also affects initial adhesion and encodes proteins from the sortase group. Microorganisms carrying this gene show increased resistance to antibiotics and host immune factors, and are more easily present in the hospital environment [35]. A group of proteins encoded by the Hld gene cause damage to the host cell membrane, leading to necrosis and apoptosis of the polynucleated and mononuclear cells. Thus, presence of this gene facilitates the proliferation and colonization abilities of the pathogenic CoNS strains [36,37]. IS256 is a sequential fragment of the entire gene, responsible for virulence. Its action is based on the reversible transposition of genes responsible for the production of biofilm or regulating its production [38]. It is believed that IS256 is associated with virulence determinant genes, contributes to genetic adaptation, and is active in invasive strains during infection. Expression of ica operon may be affected by IS256. IS256 increases the production of PIA (polysaccharide intercellular adhesin), which plays an important role in biofilm formation 
and immune system invasion [39,40]. Previous studies have reported IS256 as an important factor for S. epidermidis infectivity and a marker to differentiate the invasive and commensal S. epidermidis isolates [41-43].

In this study, CoNS strains isolated from bloodstream and identical with their counterpart strains isolated in parallel from faeces possessed no icaA gene. Presence of a ses $D$ gene also responsible for adherence was shown only in 5.5\% of strains belonging to this group. On the other hand, these strains, unlike others with discrepant PFGE profiles, i.e., unrelated to gut colonization, showed, in vast majority of cases, the presence of IS256.

The lack of the genes, responsible for adhesion to host cells and tissues, seems to allow CoNS to enter the bloodstream and cause infection. The results of our molecular studies on presence of the adherence genes in CoNS were also confirmed by our phenotyping studies on adherence to CaCo 2 cells. Strong and intermediate adherence to human cell line were more common for strains with non-identical PFGE profile, whereas strains with compatible profile mostly showed lack of adherence. We obtained similar results when examining group A streptococci from invasive infections: the most virulent strains showed no or very poor adherence to human cell cultures [26]. Maybe, in the future, checking for the absence of $i c a A$ in addition to identification and testing the drug resistance profile of CoNS isolated from newborns will be used as markers indicating high probability of sepsis.

It has been demonstrated that S. epidermidis sessile cells growing in biofilm in vivo and in vitro show different gene expression than the same but planktonic cells, and that this process is regulated by Fe-dependent mechanism [44]. It is thus probable that CoNS present in biofilm on gut mucosa may be liberated during its decomposition [45] after Fe-signalling, and then they translocate across a weak gut-blood barrier in premature neonates. Alternatively, specific CoNS cells present in gut and armoured with genes enabling tissue penetration but not biofilm formation may directly pass the barrier and cause sepsis. Such a possibility was shown in the study of Soeorg et al. [34] on S. haemolyticus mecA-positive and IS256-positive virulent strains originating from mother's milk and causing sepsis in premature neonates. Our studies also seem to support this hypothesis.

Studies on the mechanisms of CoNS utilized to evoke sepsis in premature newborns with low and very low birth weight may offer practical approaches in neonatal sepsis prevention. A broader assessment of the virulence markers of CoNS with a consistent genetic profile in blood and faeces may allow for a more accurate understanding of how these strains enter the bloodstream, and thus prevent sepsis by effective control of their colonization and translocation. For example, in our previous clinical study on the effects of administration of the probiotic L. rhamnosus and B. breve we found that gut colonization of preterm neonates with the latter bacteria resulted in a significant decrease of the CoNS-related sepsis rates. This observation offered indirect evidence that gut colonization with CoNS poses a risk of the staphylococcal neonatal sepsis in VLBR and LBR infants that may be decreased by extensive neonatal gut colonization with bifidobacteria [46].

\section{Conclusions}

One-quarter of CoNS strains isolated from bloodstream of VLBW/LWB neonates were identical to the strains isolated from faeces of the same neonates at the same time as demonstrated by PFGE profiling. The majority of the strains with identical PFGE profiles in this study belonged to $S$. haemolyticus genus.

The strains with identical PFGE profiles in comparison to those with non-identical profiles differed in pattern of the virulence genes and especially showed a lack of the genes related to adherence; indeed, they were phenotypically unable to adhere to intestinal Caco2 cells.

On the other hand, the strains with identical PFGE profiles more often showed the presence of IS256, which is related to virulence, than those with non-identical profiles.

These observations may offer indirect evidence indicating that at least some CoNS can translocate from the gastrointestinal tract of the premature neonates into the bloodstream and thus cause generalized infection.

Transparency declaration. 
Author Contributions: E.G.: Data curation, formal analysis, investigation, and writing—original draft, visualization. M.S.: Data curation, formal analysis, investigation, and writing —original draft, project administration. A.T.-P.: Methodology, formal analysis, and writing - review and editing. R.L. and D.P.: Formal analysis, resources, visualization, and writingreview and editing. G.W. and Ł.K.: Investigation, data curation. B.R.-W., J.K., and M.D.: Methodology, resources, and writing - review and editing. P.B.H.: Conceptualization, methodology, resources, and writing-original draft, supervision, project administration, and funding acquisition. All authors have read and agreed to the published version of the manuscript.

Funding: This research was funded by The National Science Center (Poland, grant number 2014/15/B/NZ6/01856 and 2018/31/B/NZ6/02443).

Conflicts of Interest: The authors declare no conflict of interest. The funders had no role in the design of the study; in the collection, analyses, or interpretation of data; in the writing of the manuscript; or in the decision to publish the results.

\section{References}

1. Shah, B.A.; Padbury, J.F. Neonatal sepsis: An old problem with new insights. Virulence 2014, 5, 170-178. [CrossRef] [PubMed]

2. Cortese, F.; Scicchitano, P.; Gesualdo, M.; Filaninno, A.; De Giorgi, E.; Schettini, F.; Laforgia, N.; Ciccone, M.M. Early and late infections in newborns: Where do we stand? A review. Pediatr. Neonatol. 2016, 57, $265-273$. [CrossRef] [PubMed]

3. Wójkowska-Mach, J.; Chmielarczyk, A.; Strus, M.; Lauterbach, R.; Heczko, P. Neonate bloodstream infections in organization for economic cooperation and development countries: An update on epidemiology and prevention. J. Clin. Med. 2019, 8, 21. [CrossRef] [PubMed]

4. Cantey, J.B.; Anderson, K.R.; Kalagiri, R.R.; Mallett, L.H. Morbidity and mortality of coagulase-negative staphylococcal sepsis in very-low-birth-weight infants. World J. Pediatr. 2018, 14, 269-273. [CrossRef]

5. Bizzarro, M.J.; Shabanova, V.; Baltimore, R.S.; Dembry, L.M.; Ehrenkranz, R.A.; Gallagher, P.G. Neonatal sepsis 2004-2013: The rise and fall of coagulase-negative staphylococci. J. Pediatr. 2015, 166, 1193-1199. [CrossRef]

6. Wójkowska-Mach, J.; Gulczyńska, E.; Nowiczewski, M.; Borszewska-Kornacka, M.; Domańska, J.; Merritt, T.A.; Helwich, E.; Kordek, A.; Pawlik, D.; Gadzinowski, J.; et al. Late-onset bloodstream infections of very-lowbirth-weight infants: Data from the Polish Neonatology Surveillance Network in 2009-2011. BMC Infect. Dis. 2014, 14, 339. [CrossRef]

7. Marchant, E.A.; Boyce, G.K.; Sadarangani, M.; Lavoie, P.M. Neonatal sepsis due to coagulase-negative staphylococci. Clin. Dev. Immunol. 2013, 2013, 586076. [CrossRef]

8. Bjarnsholt, T. The role of bacterial biofilms in chronic infections. APMIS Suppl. 2013, 136, 1-51. [CrossRef]

9. Berg, R.D. Bacterial translocation from the gastrointestinal tract. Adv. Exp. Med. Biol. 1999, 473, 11-30.

10. Deitch, E.A. Gut-origin sepsis: Evolution of a concept. Surgeon 2012, 10, 350-356. [CrossRef]

11. Bischoff, S.C.; Barbara, G.; Buurman, W.; Ockhuizen, T.; Schulzke, J.D.; Serino, M.; Tilg, H.; Watson, A.; Wells, J.M. Intestinal permeability: A new target for disease prevention and therapy. BMC Gastroenterol. 2014, 14, 189. [CrossRef] [PubMed]

12. Yajima, M.; Nakayama, M.; Hatano, S.; Yamazaki, K.; Aoyama, Y.; Yajima, T.; Kuwata, T. Bacterial translocation in neonatal rats: The relation between intestinal flora, translocated bacteria, and influence of milk. J. Pediatr. Gastroenterol. Nutr. 2001, 33, 592-601. [CrossRef] [PubMed]

13. Ciftci, I.; Ozdemir, M.; Aktan, M.; Aslan, K. Bacterial translocation and intestinal injury in experimental necrotizing enterocolitis model. Bratisl. Lek. Listy 2012, 113, 206-210. [CrossRef] [PubMed]

14. Wujtewicz, M.A.; Śledzińska, A.; Owczuk, R.; Wujtewicz, M. Escherichia coli bacteraemias in intensive care unit patients. Anaesthesiol. Intensive Ther. 2016, 48, 171-174. [CrossRef] [PubMed]

15. Soeorg, H.; Huik, K.; Parm, Ü.; Ilmoja, M.L.; Metsvaht, T.; Lutsar, I. Molecular epidemiology of staphylococcus epidermidis in neonatal intensive care units. APMIS 2017, 125, 63-73. [CrossRef]

16. Luo, C.C.; Shih, H.H.; Chiu, C.H.; Lin, J.N. Translocation of coagulase-negative bacterial staphylococci in rats following intestinal ischemia-reperfusion injury. Biol. Neonate 2004, 85, 151-154. [CrossRef]

17. Soeorg, H.; Huik, K.; Parm, U.; Ilmoja, M.L.; Metelskaja, N.; Metsvaht, T.; Lutsar, I. Genetic relatedness of coagulase-negative staphylococci from gastrointestinal tract and blood of preterm neonates with late-onset sepsis. Pediatr. Infect. Dis. J. 2013, 32, 389-393. [CrossRef] 
18. Gastmeier, P.; Geffers, C.; Schwab, F.; Fitzner, J.; Obladen, M.; Rüden, H. Development of a surveillance system for nosocomial infections: The component for neonatal intensive care units in Germany. J. Hosp. Infect. 2004, 57, 126-131. [CrossRef]

19. Guembe, M.; Martín-Rabadán, P.; Cruces, R.; Pérez Granda, M.J.; Bouza, E. Slicing silicone neonatal vascular catheter tips improves colonization detection by the roll-plate technique. Clin. Microbiol. Infect. 2017, 23, 410.e1-410.e3. [CrossRef] [PubMed]

20. Villari, P.; Sarnataro, C.; Iacuzio, L. Molecular epidemiology of staphylococcus epidermidis in a neonatal intensive care unit over a three-year period. J. Clin. Microbiol. 2000, 38, 1740-1746. [CrossRef] [PubMed]

21. Chmielarczyk, A.; Pomorska-Wesołowska, M.; Szczypta, A.; Romaniszyn, D.; Pobiega, M.; Wójkowska-Mach, J. Molecular analysis of methicillin-resistant staphylococcus aureus strains isolated from different types of infections from patients hospitalized in 12 regional, non-teaching hospitals in southern Poland. J. Hosp. Infect. 2017, 95, 259-267. [CrossRef]

22. Söderquist, B.; Andersson, M.; Nilsson, M.; Nilsdotter-Augustinsson, A.; Persson, L.; Friberg, O.; Jacobsson, S. Staphylococcus epidermidis surface protein I (SesI): A marker of the invasive capacity of S. epidermidis? J. Med. Microbiol. 2009, 58, 1395-1397. [CrossRef]

23. Soumya, K.R.; Sheela, S.; Jyothis, M.; Radhakrishnan, E.K. Studies on coexistence of mec gene, IS256 and novel sasX gene among human clinical coagulase-negative staphylococci. 3 Biotech 2016, 6, 233. [CrossRef]

24. Marconi, C.; Cunha, M.L.R.S.; Araujo, J.R.J.P.; Rugolo, L.M.S.S. Standarization of the PCR technique for the detection of delta toxin in Staphylococcus spp. J. Venom. Anim. Toxins Incl. Trop. Dis. 2005, 11, 117-128. [CrossRef]

25. Thomas, J.C.; Zhang, L.; Robinson, D.A. Differing lifestyles of staphylococcus epidermidis as revealed through Bayesian clustering of multilocus sequence types. Infect. Genet. Evol. 2014, 22, 257-264. [CrossRef] [PubMed]

26. Eftekhar, F.; Dadaei, T. Biofilm formation and detection of icaAB genes in clinical isolates of methicillin resistant Staphylococcus aureus. Iran. J. Basic Med. Sci. 2010, 14, 132-136.

27. Golińska, E.; van der Linden, M.; Więcek, G.; Mikołajczyk, D.; Machul, A.; Samet, A.; Piórkowska, A.; Dorycka, M.; Heczko, P.B.; Strus, M. Virulence factors of streptococcus pyogenes strains from women in peri-labor with invasive infections. Eur. J. Clin. Microbiol. Infect. Dis. 2016, 35, 747-754. [CrossRef]

28. Arciolaa, C.R.; Campocciaa, D.; Gamberinia, S.; Cervellatia, M.; Donatia, E.; Montanaro, L. Detection of slime production by means of an optimised Congo red agar plate test based on a colourimetric scale inStaphylococcus epidermidis clinical isolates genotyped for ica locus. Biomaterials 2002, 23, 4233-4239. [CrossRef]

29. Tenover, F.C.; Arbeit, R.D.; Goering, R.V.; Mickelsen, P.A.; Murray, B.E.; Persing, D.H.; Swaminathan, B. Interpreting chromosomal DNA restriction patterns produced by pulsed-field gel electrophoresis: Criteria for bacterial strain typing. J. Clin. Microbiol. 1995, 33, 2233-2239. [CrossRef]

30. Stewart, C.J.; Embleton, N.D.; Marrs, E.C.L.; Smith, D.P.; Fofanova, T.; Nelson, A.; Skeath, T.; Perry, J.D.; Petrosino, J.F.; Berrington, J.E.; et al. Longitudinal development of the gut microbiome and metabolome in preterm neonates with late onset sepsis and healthy controls. Microbiome 2017, 5, 75. [CrossRef]

31. Dong, Y.; Speer, C.P.; Glaser, K. Beyond sepsis: Staphylococcus epidermidis is an underestimated but significant contributor to neonatal morbidity. Virulence 2018, 9, 621-633. [CrossRef] [PubMed]

32. Donnell, S.C.; Taylor, N.; van Saene, H.K.F.; Magnall, V.L.; Pierro, A.; Lloyd, D.A. Infection rates in surgical neonates and infants receiving parenteral nutrition: A five-year prospective study. J. Hosp. Infect. 2002, 4, 273-280. [CrossRef] [PubMed]

33. Turroni, F.; Milani, C.; Duranti, S.; Lugli, G.A.; Bernasconi, S.; Margolles, A.; Di Pierro, F.; van Sinderen, D.; Ventura, M. The infant gut microbiome as a microbial organ influencing host well-being. Ital. J. Pediatr. 2020, 46, 16. [CrossRef] [PubMed]

34. Soeorg, H.; Metsvaht, H.K.; Keränen, E.E.; Eelmäe, I.; Merila, M.; Ilmoja, M.L.; Metsvaht, T.; Lutsar, I. Genetic relatedness of staphylococcus haemolyticus in gut and skin of preterm neonates and breast milk of their mothers. Pediatr. Infect. Dis. J. 2019, 38, 308-313. [CrossRef] [PubMed]

35. Qi, X.; Jin, Y.; Duan, J.; Hao, Z.; Wang, S.; Guo, Y.; Lv, J.; Hu, L.; Wang, L.; Yu, F. SesI may be associated with the invasiveness of staphylococcus epidermidis. Front. Microbiol. 2018, 4, 2474. [CrossRef]

36. Da, F.; Joo, H.S.; Cheung, G.Y.C.; Villaruz, A.E.; Rohde, H.; Luo, X.; Otto, M. Phenol-soluble modulin toxins of staphylococcus haemolyticus. Front. Cell. Infect. Microbiol. 2017, 24, 206. [CrossRef] 
37. Otto, M. Staphylococcus epidermidis: A major player in bacterial sepsis? Future Microbiol. 2017, 12, 1031-1033. [CrossRef]

38. Kleinert, F.; Kallies, R.; Hort, M.; Zweynert, A.; Szekat, C.; Nagel, M.; Bierbaum, G. Influence of IS256 on genome variability and formation of small-colony variants in staphylococcus aureus. Antimicrob. Agent Chemother. 2017, 61, 607-624. [CrossRef]

39. Otto, M. Staphylococcus epidermidis-The 'accidental' pathogen. Nat. Rev. Microbiol. 2009, 7, 555-567. [CrossRef]

40. Koskela, A.; Nilsdotter-Augustinsson, A.; Persson, L.; Soderquist, B. Prevalence of the ica operon and insertion sequence IS256 among Staphylococcus epidermidis prosthetic joint infection isolates. Eur. J. Clin. Microbiol. Infect. Dis. 2009, 28, 655-660. [CrossRef]

41. Gu, J.; Li, H.; Li, M.; Vuong, C.; Otto, M.; Wen, Y.; Gao, Q. Bacterial insertion sequence IS256 as a potential molecular marker to discriminate invasive strains from commensal strains of staphylococcus epidermidis. J. Hosp. Infect. 2005, 61, 342-348. [CrossRef] [PubMed]

42. Du, X.; Zhu, Y.; Song, Y.; Li, T.; Luo, T.; Sun, G.; Yang, C.; Cao, C.; Lu, Y.; Li, M. Molecular analysis of staphylococcus epidermidis strains isolated from community and hospital environments in China. PLoS ONE 2013, 8, e62742. [CrossRef] [PubMed]

43. Saravanan, M.; Stalin, M.; Indhumathy, K.; Padma, K. Role of insertion sequence element ISi256 as a virulence marker and its association with biofilm formation among methicillin-resistant staphylococcus epidermidis from hospital and community settings in Chennai, South India. Brief Commun. 2018, 36, 124.

44. Massonet, C.; Pintens, V.; Merckx, R.; Anné, J.; Lammertyn, E.; Van Eldere, J. Effect of iron on the expression of sirR and sitABC in biofilm-associated staphylococcus epidermidis. BMC Microbiol. 2006, 19, 103.

45. Moormeier, D.E.; Bayles, K.W.Staphylococcus aureus biofilm: A complex developmental organism. Mol. Microbiol. 2017, 104, 365-376. [CrossRef]

46. Strus, M.; Helwich, E.; Lauterbach, R.; Rzepecka-Weglarz, B.; Nowicka, K.; Wilińska, M.; Szczapa, J.; Rudnicka, M.; Sławska, H.; Szczepański, M.; et al. Effects of oral probiotic supplementation on gut Lactobacillus and Bifidobacterium populations and the clinical status of low-birth-weight preterm neonates: A multicenter randomized, double-blind, placebo-controlled trial. Infect. Drug Resist. 2018, 21, 1557-1571. [CrossRef]

(C) 2020 by the authors. Licensee MDPI, Basel, Switzerland. This article is an open access article distributed under the terms and conditions of the Creative Commons Attribution (CC BY) license (http://creativecommons.org/licenses/by/4.0/). 